\title{
Bacterial colonisation in the gut of Phlebotomus duboscqi (Diptera: Psychodidae): transtadial passage and the role of female diet
}

\author{
Petr Volf ${ }^{1}$, Alena Kiewegová ${ }^{1}$ and Alexandr Nemec $^{2}$ \\ ${ }^{1}$ Department of Parasitology, Charles University, Viničná 7, 12844 Prague 2, Czech Republic; \\ ${ }^{2}$ National Institute of Public Health, Šrobárova 48, 10042 Prague 10, Czech Republic
}

Key words: sandfly, bacteria, Ochrobactrum, Leishmania, lectin, transtadial transmission

\begin{abstract}
Bacteria isolated from the gut of different developmental stages of Phlebotomus duboscqi Neveu-Lemaire, 1906 belonged almost all to aerobic or facultatively anaerobic gram-negative rods. In females, the highest bacterial counts were observed two days after bloodfeeding; seven days after bloodfeeding the bacterial counts returned to pre-feeding levels. Most isolates were identified phenotypically as Ochrobactrum sp. The distinctiveness and homogeneity of the phenotypic and genotypic characteristics of Ochrobactrum isolates indicated that they belonged to a single strain (designated AK). This strain was acquired by larvae from food and passaged transtadially: it was isolated from the guts of fourth-instar larvae shortly before pupation, from pupae as well from newly emerged females. Most other bacteria found in females were acquired from the sugar solution fed to adults. To determine if the midgut lectin activity may serve as antibacterial agent females were membrane-fed on blood with addition of inhibitory carbohydrates. No significant differences in bacterial infections were found between experimental and control groups and we suppose that the lectin activity has no effect on gram-negative bacteria present in sandfly gut.
\end{abstract}

Bacteria occurring in the gut of haematophagous insects may have an important role in epidemiology of human infectious diseases. Such bacteria may interfere with the development of medically important pathogens. For example, high midgut counts of gram-negative bacteria are known to significantly reduce oocyst numbers in Plasmodium-infected mosquitoes (Seitz et al. 1987, Beier et al. 1994, Pumpuni et al. 1996). A high prevalence of microbial infection in the digestive tract of wild-caught Phlebotomus females was suggested to have a negative effect on Leishmania transmission in endemic areas (Schlein et al. 1985).

Sandfly females may ingest bacteria while feeding on blood or sugar-meal. Blood-meals are usually sterile, while sugar-meals from different sources may contain a variety of contaminating microorganisms. The present study has two parts. The aim of the first part was to examine the prevalence of bacteria in the gut of various developmental stages of Phlebotomus duboscqi, NeveuLemaire, 1906 and compare the number of bacteria present in females before and after bloodfeeding. Interestingly, preliminary experiments detected the presence of bacteria in newly emerged females that had never fed. This finding drew our attention to the possibility of transtadial transmission since the passage of bacteria from larvae to adults was not previously reported in sandflies.

The second part of the work was aimed at elucidating the role of midgut lectin activity in bacterial infections. Arthropod lectins are known to be employed in immune and defence reactions based on recognition of self/non- self and they can act as opsonins participating in phagocytosis of microorganisms (for review see Olafsen 1996). In vectors of infectious diseases lectins have a regulatory role in the refractoriness/susceptibility to transmitted trypanosomatid parasites (for review see Welburn and Maudlin 1999). Studies carried out on various sandfly species demonstrated the presence of gut lectin activity specific for aminosugars and heparin (for review see Grubhoffer et al. 1997). The activity theoretically serves as one of factors affecting sandfly susceptibility to Leishmania infections (Volf et al. 1998); however, no information is available about its role in bacterial infections. To determine if the midgut lectin activity may serve as an antibacterial agent, females were membrane-fed on blood with addition of inhibitory carbohydrates.

\section{MATERIALS AND METHODS}

Sandfly colonies. The Senegal strain of Phlebotomus duboscqi Neveu-Lemaire, 1906 was obtained from Prof. Killick-Kendrick in 1994. The colony was maintained at $26^{\circ} \mathrm{C}$ and LD 14:10 photoperiod. Adults had a permanent access to cotton wool soaked by $50 \%$ sucrose. The stock solution of sucrose was sterilized by boiling in a microwave oven and the cotton wool was changed four times a week. Once a week females were allowed to feed for $1 \mathrm{~h}$ on anesthetized mice. Larvae were fed on mixture of dried rabbit faeces and rabbit food. This mixture was aged in humid and aerobic conditions for three weeks, then dried, ground and stored in plastic containers at $-20^{\circ} \mathrm{C}$ until use. 
Effect of bloodfeeding and addition of inhibitory sugars. Six- to eight-day-old female sandflies were either fed on anesthetized mice or membrane-fed on blood with addition of carbohydrate inhibitors of lectin activity as described previously by Volf et al. (1998). Briefly, sterile stock solutions of galactosamine or galactose $(250 \mathrm{mM})$ and heparin $(2500$ $\mathrm{U} / \mathrm{ml}$ ) were made up in phosphate buffered saline, $\mathrm{pH} 7.4$ (PBS). Females were fed through chick-skin membrane on citrated and heat-inactivated human blood with added sugar solutions. In the first experiment, galactosamine was used as an inhibitor and galactose served as a noninhibitory control. The final concentration was $50 \mathrm{mM}$ for both monosaccharides. In the second experiment one group of females was fed on heparin (final concentration $500 \mathrm{U} / \mathrm{ml}$ ) while in controls PBS alone was added into the blood-meal. Each feeding experiment was repeated twice.

Engorged females were maintained separately in clean cages at $26^{\circ} \mathrm{C}$ and dissected $48 \mathrm{~h}$ and seven days after feeding. Before dissection, females were anesthetized by chilling on ice and surface-sterilized for $1 \mathrm{~min}$ in $70 \%$ ethanol. Each specimen was then washed in sterile isotonic saline and transferred to drop of saline on sterile slide. The gut (hindgut and midgut) with Malpighian tubules was dissected out using sterile needles, transferred into sterile Eppendorf tube with $500 \mu 1$ of saline and homogenized under sterile conditions using a motorized pellet pestle.

To determine the number of colony forming units (CFU), the sample was serially diluted ten times (from $1: 10$ to 1 : 100 000) in sterile saline. From each dilution, $100 \mu 1$ of the sample was spread onto the surface of Petri dishes $(90-\mathrm{mm}$ diameter) containing trypton soya agar (TSA) (Bridson 1995). The dishes were incubated for $3-5$ days at $30^{\circ} \mathrm{C}$. Total colony counts were recorded in each dilution and the average for every sample was calculated. Representative colonies were subcultured on TSA and stored in glycerol broth at $-80^{\circ} \mathrm{C}$ for further identification.

Prevalence of bacteria in various developmental stages. The following developmental stages of $P$. duboscqi were examined for bacterial presence: fourth-instar larvae actively feeding (with gut filled with larval diet), fourth-instar larvae ready to moult (with "milky" gut because of defecated midgut content), pupae before emerging (with dark brown eyes), and newly emerged females (less than $12 \mathrm{~h}$ old). Bacteria were not quantified in this experiment.

Before dissection, larvae and pupae were surface-sterilized for $10 \mathrm{~min}$ in $96 \%$ ethanol; adult females were knocked down on ice and surface-sterilized for $1 \mathrm{~min}$ in $70 \%$ ethanol. Each specimen was then washed in sterile isotonic saline and transferred to drop of saline on sterile slide. The guts were dissected and gut homogenates were prepared as described above. In larvae with food-filled guts the suspension was diluted 1: 100 because of high bacterial numbers present. One hundred $\mu 1$ of suspension was spread onto the Petri dish with TSA and incubated as described above. Total colony counts were recorded. Representative colonies were subcultured and stored for identification under conditions described above.

Possible sources of contamination were studied by isolation of bacteria from larval food, stock solution of sucrose used as a sugar-meal for adults and from the chicken skin prepared for experimental membrane-feeding.
Bacterial identification. Bacteria were identified using the standard bacteriological methods (Lennette et al. 1985). Biochemical properties of the isolates belonging to Enterobacteriaceae and glucose nonfermenting gram-negative bacteria were investigated by the API20E and API20NE systems (BioMerieux), respectively. The interpretation of these results was based on numerical probabilistic identification using ApiLab Plus 3.3.3 software package (BioMerieux). The strain identity of Ochrobactrum isolates was investigated by random amplified polymorphic DNA analysis (RAPD) using primer DAF4 (Grundmann et al. 1997).

\section{RESULTS}

Bacterial identification. With a few exceptions all isolates belonged to aerobic or facultatively anaerobic gram-negative rod-shaped bacteria. Using the API20NE system, the majority of the isolates were allocated to Ochrobactrum anthropi with high identification probability (99.9\%). All these isolates shared distinctive and homogeneous biochemical (API20NE code 1243315) and morphological properties (uniform colony morphology). In addition, four isolates obtained at different time intervals yielded almost identical DAF4RAPD fingerprints (data not shown). Based on these results, the $O$. anthropi-like isolates were considered as a population of a single strain designated AK. Strain AK was then submitted to the Czech Collection of Microogranisms (Brno, Czech Republic), where the genus identity of this strain was confirmed but species identity remained elusive. These organisms are therefore designated as strain AK of Ochrobactrum sp. in the present study.

Bacteria of various sandfly stages. Results of bacterial isolations from forth-instar larvae, pupae and freshly emerged females are listed in Fig. 1. Bacterial infections were isolated from guts of all 40 fourth-instar larvae studied. In actively feeding larvae, whose gut was filled with larval food, a great variety of bacterial species was found. Strain AK was present in about two thirds of individuals, often accompanied by other bacteria. On the other hand, in larvae with empty guts, strain AK was the only bacterium identified; it was isolated in $95 \%$ of larvae (Fig. 1). In pupae, most individuals either harboured strain AK (41\%) or were sterile (41\%). Isolates from the rest of the pupae included Pseudomonas sp., Oligella sp. and few specimens which could not be identified by methods used (Fig. 1).

Experiments showed that most sandflies are not free of bacterial flora upon emergence. In the gut of newly emerged females, the diversity of bacterial infections was similar to that in pupae: almost two thirds of individuals (64\%) harboured strain $\mathrm{AK}$ and 30\% were sterile (Fig. 1). In $6 \%$ of females, other gram-negative bacteria (Enterobacter gergoviae and Sphingobacterium spiritivorum) were found. In most cases the infection was present in both regions of the gut, in the pylorus 


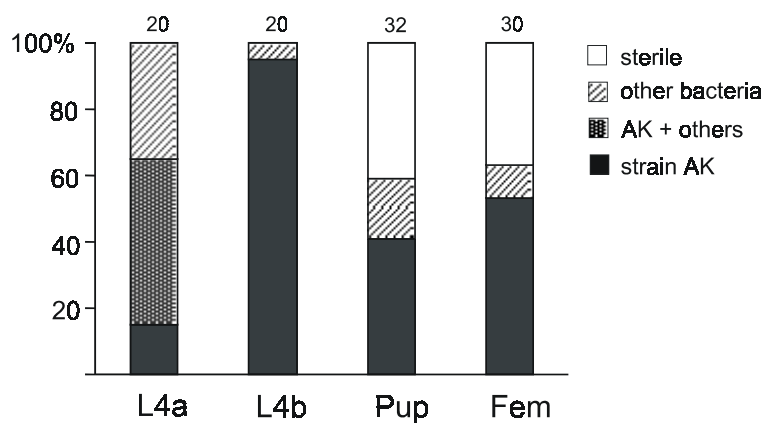

Fig. 1. Prevalence of bacteria in the gut of various developmental stages of Phlebotomus duboscqi: fourth-instar larvae actively feeding (L4a), fourth-instar larvae ready to moult (L4b), pupae just before hatching (Pup) and freshly hatched females (Fem).

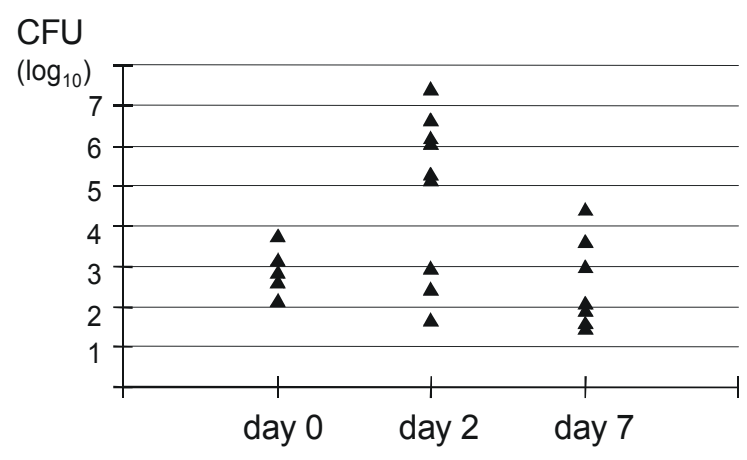

Fig. 2. Bacterial numbers in the gut of Phlebotomus duboscqi females that did not take blood (day 0) and in females that took blood two and seven days ago (day 2 and day 7, respectively). Bacterial numbers are given is colony-forming units (CFU).

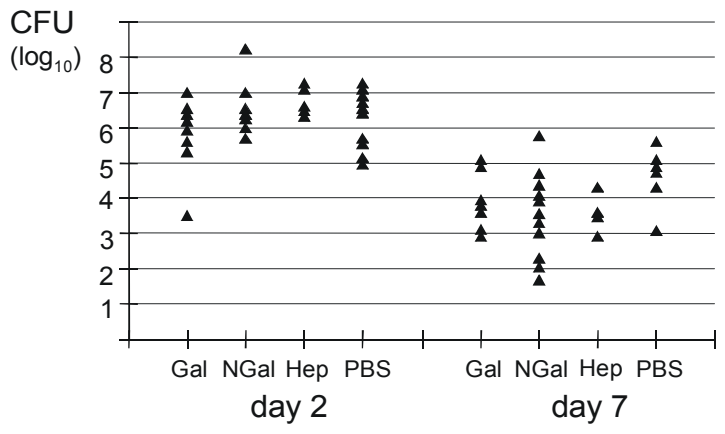

Fig. 3. Bacterial numbers (CFU) in the gut of Phlebotomus duboscqi females fed on blood with addition of carbohydrates diluted in PBS: $50 \mathrm{mM}$ galactose (Gal), $50 \mathrm{mM}$ galactosamine (NGal), heparin $500 \mathrm{U} / \mathrm{ml}$ (Hep). PBS alone served as a control.

region with Malpighian tubules as well as in the midgut. In three cases, however, strain AK was cultivated from the pylorus region only.
Study on possible sources of bacterial infection revealed the presence of Serratia marcescens, Citrobacter sp. and Stenotrophomonas maltophilia in sucrose solutions. Various bacteria, including high number of colonies of strain AK were found in diluted larval food. Few uniform colonies isolated from chick-skin membrane did not correspond with any bacteria identified from female midguts.

Effect of bloodfeeding. The prevalence of bacterial species isolated from $P$. duboscqi females which did not take blood and those dissected two and seven days after bloodfeeding is summarised in Table 1: $42 \%$ to $69 \%$ of female sandflies were found to contain bacteria. Differences between groups of females were not statistically significant $\left(\chi^{2}=1.9, P=0.38\right)$. In four cases, two different bacterial strains were isolated from the same female.

The average bacterial numbers for all unfed and bloodfed females dissected are shown in Fig. 2. The highest counts were observed two days after bloodfeeding, differences between groups, however, were not statistically significant $\left(\chi^{2}=1.12, \mathrm{P}=0.35\right)$ because of the wide variation in bacterial numbers present in individually dissected guts. Seven days after bloodfeeding, the bacterial counts were roughly back to the pre-feeding levels.

Effect of carbohydrate inhibitors. Females fed on blood with added carbohydrates were dissected two or seven days after feeding. The relative prevalence of bacterial species found is summarised in Table 2. Again, strain AK and other gram-negative rods were present. The number of females with a sterile gut did not significantly differ between galactosamine and galactose groups $\left(\chi^{2}=3.0, P=0.39\right)$. In experiments with heparin, significant differences were found on day 2 only; higher bacterial numbers were found in the control group fed on blood with PBS $\left(\chi^{2}=5.6, \mathrm{P}=0.02\right)$.

Bacterial numbers are given in Fig. 3. There was no statistical difference between pairs of groups. However, higher bacterial numbers were observed on day 2 after bloodfeeding in all four groups.

Table 1. Number of bacterial isolates from the gut of Phlebotomus duboscqi females of various bloodfeeding status: unfed on blood, two and seven days after bloodfeeding on mice.

\begin{tabular}{|c|c|c|c|}
\hline $\begin{array}{c}\text { Females } \\
(\mathrm{n})\end{array}$ & $\begin{array}{c}\text { unfed } \\
(12)\end{array}$ & $\begin{array}{c}\text { day 2 } \\
(13)\end{array}$ & $\begin{array}{c}\text { day 7 } \\
(13)\end{array}$ \\
Infected & $42 \%$ & $69 \%$ & $54 \%$ \\
\hline Ochrobactrum sp., strain AK & 5 & 9 & 6 \\
Serratia marcescens & 1 & 0 & 0 \\
Stenotrophomonas maltophilia & 0 & 1 & 1 \\
\hline Nonidentified & 0 & 1 & 1 \\
\hline
\end{tabular}


Table 2. Number of bacterial isolates from the gut of females membrane-fed on blood with carbohydrate inhibitors of lectin activity: galactosamine (NGal) and heparin (Hep). Controls included noninhibitory carbohydrate galactose (Gal) and PBS. Females were dissected 2 and 7 days after feeding.

\begin{tabular}{|c|c|c|c|c|c|c|c|c|}
\hline \multirow[b]{2}{*}{$\begin{array}{l}\text { Females fed on } \\
\text { (n) }\end{array}$} & \multicolumn{4}{|c|}{ day 2} & \multicolumn{4}{|c|}{ day 7} \\
\hline & $\begin{array}{l}\mathrm{NGal} \\
(12)\end{array}$ & $\begin{array}{r}\mathrm{Gal} \\
(11)\end{array}$ & $\begin{array}{l}\text { Hep } \\
(9)\end{array}$ & $\begin{array}{l}\text { PBS } \\
(10)\end{array}$ & $\begin{array}{l}\text { NGal } \\
(16)\end{array}$ & $\begin{array}{r}\mathrm{Gal} \\
(16)\end{array}$ & $\begin{array}{l}\text { Hep } \\
(13)\end{array}$ & $\begin{array}{l}\text { PBS } \\
(12)\end{array}$ \\
\hline Infected (\%) & 58 & 73 & 56 & 100 & 69 & 44 & 31 & 56 \\
\hline $\begin{array}{l}\text { Ochrobactrum sp., strain AK } \\
\text { Serratia marcescens } \\
\text { Stenotrophomonas maltophilia } \\
\text { Citrobacter } \text { sp. }\end{array}$ & 7 & 6 & $\begin{array}{l}3 \\
3\end{array}$ & $\begin{array}{l}6 \\
4 \\
2\end{array}$ & 8 & 6 & $\begin{array}{l}1 \\
1\end{array}$ & $\begin{array}{l}4 \\
1\end{array}$ \\
\hline Nonidentified & & 1 & & & 3 & & 2 & 1 \\
\hline
\end{tabular}

\section{DISCUSSION}

Bacterial isolations revealed the frequent presence of gram-negative bacteria in the gut of various developmental stages of Phlebotomus duboscqi. Aerobic and facultatively anaerobic gram-negative rods are ubiquitous bacteria growing easily on the type of medium used which may support their higher prevalence in sandfly midgut. Our results fit with those obtained by other studies of the midgut tissue of colonised as well as wildcaught mosquitoes and sandflies. The frequent presence of gram-negative rods belonging mostly to Enterobacteriaceae was demonstrated in adults of Culex (Chao and Wistreich 1959, 1960, Ferguson and Micks 1961) as well as Anopheles species (DeMaio et al. 1996, Pumpuni et al. 1996). Similarly, in laboratory-bred and wild-caught sandflies all predominant species identified by Dillon et al. (1996) were Enterobacteriaceae. On the other hand, gram-positive bacteria were less frequently found in sandflies (Schlein et al. 1985, Dillon et al. 1996). It appears likely that the antimicrobial activity effective against Micrococcus luteus and Bacillus subtilis, recently demonstrated by our group in midgut extracts of Lutzomyia and Phlebotomus species (Kiewegová 1999), may render these insects less susceptible to colonisation by gram-positive bacteria.

Dillon et al. (1996) showed that the number of bacteria present in the gut of Phlebotomus papatasi changes during the lifetime of a female. Here we studied the effect of bloodfeeding status: in both types of bloodfeeding, on anesthetized mice and on chick-skin membrane, the highest bacterial counts were observed two days after blood ingestion. The protein-rich bolus of the blood presumably caused rapid growth of midgut bacteria and when digestion was completed (on day 4-5) most bacteria were defecated with blood remains. Similar trends were found in mosquitoes where midgut bacterial counts peaked $48 \mathrm{~h}$ after blood ingestion and then decreased to pre-blood-meal levels as a result of digestion and excretion (DeMaio et al. 1996, Pumpuni et al. 1996).

The addition of carbohydrate inhibitors (galactosamine and heparin) into the blood-meal did not affect bacterial counts in sandfly midgut. Therefore, we suppose that the midgut lectin activity of sandflies has no effect on bacterial infections.

Specific attention was paid to the most prevalent strain AK of the genus Ochrobactrum. The nonfermentative gram-negative bacteria Ochrobactrum anthropi is known as a potential human pathogen (Kern et al. 1993). Strain AK was isolated from the gut of fourthinstar larvae just before pupation, the gut of females ready to emerge from pupae as well from midgut and hindgut of newly emerged adult females. Study on possible sources of infection showed that larvae acquire this strain, together with other bacteria, from the environment with larval food. Contrary to other bacteria, strain AK was able to survive the mechanical shedding of the larval midgut shortly before pupation and was transmitted transtadially. Its presence in the gut of individuals ready to emerge from pupa was confirmed by indirect fluorescence in sections; specific polyclonal antibodies raised in rabbits gave a positive reaction with bacteria localised in the gut lumen (Kiewegová 1999). On TSA the strain AK yielded mucoid colonies which indicates an extensive production of glycocalyx. This may enable this strain to colonise the sandfly gut and survive during transtadial passage.

In Diptera, most extracellular bacteria present in the gut are not able to survive transtadial passage, mainly because of drastic changes in the gut environment and increased secretion of antibacterial compounds during pupal stage. However, the study carried out on laboratory-reared Anopheles mosquitoes showed that newly emerged adults harboured bacteria in their midgut and transtadial transmission was demonstrated by successfully passaging Escherichia coli from the larval to the adult stage (Pumpuni et al. 1996).

While strain AK was passaged to adults transtadially most other bacteria found in adults were acquired from the sugar-meal. Some of them, like Serratia sp., are known to be pathogenic for insects (Seitz et al. 1987) and we found them in high numbers in dead or dying blood-fed females (data not shown). Moreover, the microbial colonisation of the gut is known to adversely affect the development of transmitted parasites (Seitz et 
al. 1987, Beier et al. 1994, Pumpuni et al. 1996). In sandflies, this point was raised for the first time by Adler and Theodor (1929) and later studied on laboratory-reared P. papatasi by Schlein et al. (1985), who demonstrated that fungi-infected sandfly females were refractory to infections with Leishmania major. Our study suggests that bacteria passaged transtadially or acquired from the sugar-meal offered to adults in laboratory conditions may overgrow shortly after blood- feeding and cause the mortality of females or negatively affect experimental infection by Leishmania parasites.

Acknowledgements. We thank Ms. Květa Gavurová for skilled technical assistance and A. Richardson for linguistical improvement of the manuscript. The study was supported by the Ministry of Education (projects VS 96142 and J13/981131-B4) and the Grant Agency of the Czech Republic (project 206/99/1389).

\section{REFERENCES}

ADLER S., THEODOR O. 1929: Attempts to transmit Leishmania tropica by bite: the transmission of L. tropica by Phlebotomus sergenti. Ann. Trop. Med. Parasitol. 23: 1-18.

BEIER M.S., PUMPUNI C.B., BEIER J.C., DAVIS J.R. 1994: Effects of para-aminobenzoic acid, insulin, and gentamycin on Plasmodium falciparum development in anopheline mosquitoes (Diptera: Culicidae). J. Med. Entomol. 31: 561-565.

BRIDSON E.I. 1995: The Oxoid Manual. Unipath Limited, Hampshire.

CHAO J., WISTREICH G.A. 1959: Microbial isolations from the mid-gut of Culex tarsalis Coquillet. J. Insect Pathol. 1: 311-318.

CHAO J., WISTREICH G.A. 1960: Microorganisms from the mid-gut of larval and adult Culex quinquefasciatus Say. J. Insect Pathol. 2: 220-224.

DeMAIO J., PUMPUNI C.B., KENT M., BEIER J.C. 1996: The midgut bacterial flora of wild Äedes triseriatus, Culex pipiens and Psorophora columbiae mosquitoes. Am. J. Trop. Med. Hyg. 54: 219-223.

DILLON R.J., ELKORDY E., SHEHATA M., LANE R.P. 1996: The prevalence of a microbiota in the digestive tract of Phlebotomus papatasi. Ann. Trop. Med. Parasitol. 90: 669-673.

FERGUSON M., MICKS D.W. 1961: Microorganisms associated with mosquitoes: I. Bacteria isolated from the mid-gut of adult Culex fatigans Wiedemann. J. Insect Pathol. 3: 112-119.

GRUBHOFFER L., HYPŠA V., VOLF P. 1997: Lectins (hemagglutinins) in the gut of the important disease vectors. Parasite 4: 203-216.

GRUNDMANN H.J., TOWNER K.J., DIJKSHOORN L., GERNER-SMIDT P., MAHER M., SEIFERT H., VANEECHOUTTE M. 1997. Multicenter study using standardized protocols and reagents for evaluation of reproducibility of PCR-based fingerprinting of Acinetobacter spp. J. Clin. Microbiol. 35: 3071-3077.

KERN W.V., OETHINGER M., KAUFHOLD A., ROZDZINSKI E., MARRE R. 1993. Ochrobactrumanthropi bacteremia - report of 4 cases and short review. Infection 21: 306-310.

KIEWEGOVÁ A. 1999: Antimikrobiální aktivity Phlebotomus duboscqi. Unpubl. M.Sc. Thesis, Charles University, Prague, 81 pp.

LENNETTE E.H., BALOWS A., HAUSLER W.J., SHADOMY H.J. 1985: Manual of Clinical Micro-biology. Fourth Edition. American Society for Microbiol-ogy, Washington D.C., $1150 \mathrm{pp}$.

OLAFSEN J.A. 1996: Lectins: models of natural and induced molecules in invertebrates. In: E.L. Cooper (Ed.), Advances in Comparative and Environmental Physiology. Vol. 24. Springer-Verlag, Berlin, Heidelberg, pp. 49-76.

PUMPUNI C.B., DeMAIO J., KENT M., DAVIS J.R., BEIER J.C. 1996: Bacterial population dynamics in three anopheline species: impact on Plasmodium sporogonic development. Am. J. Trop. Med. Hyg. 54: 214-218.

SCHLEIN Y., POLACHECK I., YUVAL B. 1985: Mycoses, bacterial infections and antibacterial activity in sandflies (Psychodidae) and their possible role in the transmission of leishmaniasis. Parasitology 90: 57-66.

SEITZ H.M., MAIER W.A., ROTTOK M., BECKERFELDMANN H. 1987: Concomitant infections of Anopheles stephensi with Plasmodium berghei and Serratia marcescens: additive detrimental effects. Zbl. Bakt. Hyg. 266: 155-166.

VOLF P., KIEWEGOVÁ A., SVOBODOVÁ M. 1998: Sandfly midgut lectin: effect of galactosamine on Leishmania major infections. Med. Vet. Entomol. 12: 151154.

WELBURN S.C., MAUDLIN I. 1999: Tsetse-trypanosome interactions: rites of passage. Parasitol. Today 15: 399403.

Accepted 13 June 2001 